\title{
ПРОНОМІНАЛЬНІСТЬ ПОЕТИЧНОГО МОВЛЕННЯ ЯК ОЗНАКА АВТОРСЬКОГО СТИЛЮ (НА МАТЕРІАЛІ ТВОРЧОСТI ПОЕТІВ-ШІСТДЕСЯТНИКІВ)
}

\author{
ОЛЕНА ОЛЕКСЕНКО \\ Харківський національний педагогічний університет імені Г. С. Сковороди, \\ Харків - Україна \\ PRONOMINALIZACJA JĘZYKA POETYCKIEGO \\ JAKO CECHA STYLU AUTORSKIEGO \\ (NA MATERIALE TWÓRCZOŚCI POETÓW \\ OKRESU LAT 60-TYCH XX WIEKU) \\ OLENA OLEKSENKO \\ Charkowski Narodowy Uniwersytet Pedagogiczny im. H. Skoworody, \\ Charków - Ukraina
}

STRESZCZENIE. W artykule scharakteryzowano semantykę poetycką zaimków pierwszej i drugiej osoby jako jednostek autosemantycznych, kondensujących dominanty znaczeniowe, które kształtują komunikatywny zakres utworów w liryce I. Dracza, B. Olijnyka, M. Winhranowskiego, L. Kostenko. Opisano typy referencyjne semantyzacji tych pronominatywów i wykazano cechy zawartości treściowej przez pryzmat swoistości typu psychologicznego każdego z poetów.

\section{PRONOMINALITY OF POETIC SPEECH AS A FEATURE OF AUTHOR'S STYLE (ON THE MATERIAL OF POETS OF THE $60^{\mathrm{TH}}$ )}

\section{OLENA OLEKSENKO}

H. S. Skovoroda Kharkiv National Pedagogical University, Kharkiv — Ukraine

ABSTRACT. The article presents the characteristics of poetic semantics of the 1st and 2nd person pronouns as autosemantic units - the condencers of sence dominants that form the communicative frame of lyrics of the poets of the $60^{\text {th }}$, I. Drach, B. Olijnyk, M Vingranovskiy, L Kostenko. The types of referential semantization of these pronominal units are defined and pecularities of their content fullness through the prysm of each poet's psychological type are revealed.

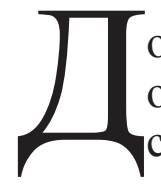

ослідники поетичного мовлення неодноразово відзначали, що в умовах обмеженого мовного простору ліричного твору семантична структура слова набуває кількох змістових рівнів. В. Виноградов писав: „Поетичне слово двопланове: співвідносячись зі словесною системою загальної мови $<\ldots>$, воно в той же час за своїми внутрішніми поетичними формами, за своєю поетичною сутністю і змістом скероване на символічну структуру літературнохудожнього твору загалом"1.

${ }^{1}$ В. В. Виноградов, Поэтика русской литературы, Москва 1972, с. 6. 
У рамках поетичного тексту процеси семантичного нарощення змісту притаманні всім частинам мови. Естетичне й смислове навантаження містять як повнозначні, так і службові слова, ядерні і периферійні частини мови. Активну роль у цьому процесі відіграють зокрема й займенники.

Визначення їхнього смислового навантаження в поетичному мовленні заслуговує на увагу вже тому, що цей клас слів у мовознавстві одержав неоднозначне тлумачення. Поширеною є думка, що займенники в повсякденній мовленнєвій практиці - другорядний лексичний розряд, що не має ні самостійного значення, ні відповідного стилістичного забарвлення. Однак закони художньої творчості діють так, що „розряд займенників, незначущий в узуальній мовній системі, системою вірша висувається на передній план, додатково семантизується, укрупнюється"'.

Як відомо, у визначенні змістового аспекту займенників лінгвісти не дійшли згоди, оскільки дослідження здійснюються із різних позицій і „відмінності в потрактуваннях часто пов'язані з акцентуванням уваги на різних аспектах значення або функціонування займенників"з. Поширеним є погляд на прономінативи як актуалізатори в мовленні різних типів референції іменної групи (функція заміщення). В останній час у зв’язку із увагою до вивчення структури тексту набули актуальності розвідки про текстотвірні (анафоричні) функції займенників, проте часом вони зводяться до правил синтаксичного вживання цих слів. Однак особливої ваги у вивченні природи займенника і його призначення в мові набувають праці, написані під впливом інтересу до прагматичного аспекту мовних знаків загалом (Т. Космеда, Л. Синельникова та ін.), оскільки, як зазначає О. Селіверстова, займенники, маючи не номінативне, а дейктичне значення, не ідентифікують денотат, а дають характеристику актанту4. Т. Сільман наголошує, що функцію заміщення займенники виконують лише за умови чергування $з$ повнозначною лексикою, замінюючи яке-небудь попереднє чи наступне слово контексту: той, цей, він, вона, там, тут тощо. Якщо ж цього немає, відсутня мовленнєва ситуація ,антецедент - субститут”, тоді займенники вільно розвивають другу із своїх найважливіших функцій - автосемантичного позначення особи всередині акту комунікації. „Це - особливого роду функція, не менш унікальна, ніж функція повнозначної лексики" 5 .

Автосемантичність прономінативів найбільш яскраво виявляється в поетичному тексті, зокрема в ліриці, що насичена займенниками 1-ї та 2-ї особи однини й, меншою мірою, - множини. Те, що лірика - мистецтво прономінальної скерованості, відзначалося неодноразово (Д. Овсянико-Куликовський, Л. Булаховський, В. Виноградов, Р. Якобсон, Т. Сільман, С. Золян, Л. Мацько, Я. Гін, І. Циганок та ін.). Ім’я в сучасній ліриці зазвичай взагалі не називається. „Безіменність закладена в самій природі ліричного жанру, оскільки лірика відображає певну „комунікативну ситуацію”, а саме - особисте, інтимне звертання поета або до іншого Я, або до природи, світу, всесвіту, і все це на рівні глибинної інтроспекції. Єдино можливою формою вираження особистості в цих умовах є займенник, безіменне Я, ліричне „інкогніто"” 6.

\footnotetext{
${ }^{2}$ О. Н. Сели верстов в, Местоимения в языке и речи, Москва 1988, с. 48.

${ }^{3}$ Там же, с. 4.

${ }^{4}$ Там же, с. 5.

${ }^{5}$ Т. И. Сильман, Синтактико-стилистические особенности местоимений (на материале немеикого языка), [в:] "Вопросы языкознания”, 1970, № 4, с. 83.

${ }^{6}$ Там же, с. 83-84.
} 
Безіменність, а отже, й семантична визначеність передусім займенників Я, ТИ, МИ, ВИ має свою шкалу вираження в ліричній мові різних поетів. Припускаємо, що це залежить від різноманітних екстралінгвальних чинників, зокрема значною мірою й від психічного устрою кожного із авторів. Неможливо наблизитися до осягнення авторської картини світу, розуміння суті творчого процесу письменника, вияву його власного Я без занурення в психологію поета, адже цей крок дає змогу більш виразно простежити особливості поетики, визначити витоки художності, оскільки поезія - це жанр, у якому автор викидає свою психічну енергію, репрезентує рух рефлексій, що розкривають глибину його почувань.

Аналіз психологічної сутності письменника бере витоки з наукових студій О. Потебні, Д. Овсянико-Куликовського, І. Франка, В. Вундта, Л. Виготського, О. Білецького та праць із психології К.-Г. Юнга, В. Айзенка та ін. До проблем психології творчості в сучасній філології та психології звертаються В. Агеєва, Т. Гундорова, Н. Зборовська, С. Ільїн, Г. Клочек, М. Кодак, С. Михида, С. Павличко, В. Романець та ін. О. Потебня, спираючись на теорію В. фон Гумбольдта про єдність мови й мислення, доводив, що художня творчість відображає внутрішній світ митця. Таємниці мистецтва, як зазначав учений, слід убачати в особливостях душі письменника, який творить передусім для себе, тому художній твір постає іiі моделлю. Однак сила твору не в тому, що мав на думці автор, а в тому, як цей твір діє на читача, відтак у невичерпно можливому його змісті ${ }^{7}$.

У цьому сенсі увагу привертає творчість поетів-шістдесятників, зокрема мова їхньої поезії — образна, афористична, насичена символічними смислами, яскравими асоціаціями, що будять думку. Лінгвістичний аспект творчої лабораторії окремих представників шістдесятництва досліджували Т. Беценко, А. Бондаренко, Т. Можарова, А. Нечипоренко, Л. Олефіренко, І. Павлова, О. Росінська, Г. Сюта та ін. Смислові акценти, породжені вживанням такого специфічного класу слів, як займенники, зокрема особові, в ідіостилі І. Драча та М. Вінграновського з урахуванням психічного типу автора ми дослідили раніше ${ }^{8,9}$. Однак узагальнювальної характеристики вживання особових прономінативів, які $є$ домінантами, що здатні максимально конденсувати приховані смисли, виявляти додаткові відтінки значень, формуючи комунікативну рамку твору, з огляду на особливості психотипу поетів-шістдесятників досі немає. Необхідність такого дослідження вбачаємо у важливості вивчення взаємозв'язку психічного світу авторів, яких відносимо за низкою ознак (див. роботи К.-Г. Юнга, Л. Лисиченко, Т. Скорбач, Т. Ковальової. І. Павлової та ін.) ${ }^{10}$ до інтровертів (М. Вінграновський, Л. Костенко) чи екстравертів (І. Драч, Б. Олійник), з характером вербалізації внутрішнього Я та світу довкола нього. Це й зумовлює актуальність проблеми, порушеної в цій статті.

${ }^{7}$ О. О. Потебня. Естетика і поетика слова, Київ, 1985.

${ }^{8}$ О. А. Олексен ко, Займенники в поетичному мовленні І. Драча: семантика і функиії, [в:] „Мова. Культура. Взаєморозуміння”, за ред. Т. А. Ко см еди, Дрогобич 2012, вип. 2, с. 220-228.

${ }^{9}$ О. А. Олексенко, Функційно-семантична своєрідність прономінативів зі значенням особи в ліриці М. Вінграновського, [в:] „Лінгвістичні студіі”, за ред. А. П. Загнітка, Донецьк 2013, вип. 27, с. 51-55.

${ }^{10}$ К.-Г. Юнг, Психологія та поезія, [в:] Антологія світової літературно-критичної думки XX ст., Львів 2002, с. 119-141; Л. А. Лисиченко, Т. В. Скорбач, Мовний образ простору і психологія поета, Харків 2001; Т. В. Ковальова, Лексико-семантичні поля кольоративів в українській поезії початку ХХ ст., Харків, 1999; І. Павлова, Числівник у художньому тексті поетів-шістдесятників: структура, семантика, функиії, Харків, 2011. 
Мета цього дослідження - узагальнити особливості змістового наповнення займенників 1-ї та 2-ї особи й співвідносних із ними присвійних займенників у мові поезій М. Вінграновського, Л. Костенко, І. Драча, Б. Олійника як вияву характеру авторського стилю, зумовленого приналежністю митців до різних психотипів. Для досягнення цієї мети необхідно виконати такі завдання: 1) окреслити смислову домінанту у вживанні займенника Я в ліриці кожного з названих поетів; 2) 3'ясувати особливості семантичних відношень займенника Я з ТИ, МИ, ВИ; 3) диференціювати ступінь визначальності семантики цих займенників для ідіостилю поетів-інтровертів та поетів-екстравертів.

Предмет вивчення - функціонально-смислова навантаженість зазначених вище займенників у мові лірики поетів-шістдесятників, а матеріалом для написання статті послужили поезії збірок І. Драча „Сонце і слово”, Б. Олійника „Заклинання вогню” та „Істина”, М. Вінграновського „Цю жінку я люблю”, Л. Костенко „Річка Геракліта”.

Існує думка, що в ліриці „головним” займенником виступає Я, оскільки він природно пов'язаний зі способом вираження так званого „ліричного героя”. Це поняття в літературознавстві неодноразово дискутувалося, уточнювалося й на цю пору обросло синонімічними зворотами: „ліричний персонаж”, „ліричне Я”, „ліричний характер” тощо. На думку Ю. Тинянова, „голос автора” („особа автора”, „авторське Я”, „первинний автор”), що сприймається нами, є вже витвір мистецтва, художній об'єкт, реальність іншого типу, ніж життєва, це Я вже не творець, будівничий поетичного світу, а мешканець створеного світу" ${ }^{11}$. Цей мешканець створеного автором світу безпосередньо виражає себе займенником 1-ї особи однини. У таких суб'єктивно ліричних висловлюваннях не звучить ім'я автора, що свідчить про ідентичність авторського й ліричного Я.

Лінгвісти по-різному окреслюють типи семантизації займенника Я, однак їх можна звести до таких: „особистісне Я”, „функціональне Я”, „зіставне Я”, „Я ліричного персонажа”, „опредметнене Я”, „Я уособленого персонажа"12. Причому перші три типи можна об'єднати у „власне Я”, що протиставляється трьом іншим як „чужому Я’.

Одна $з$ рис творчої манери поетів екстравертивного типу, до яких, як уже зазначалося, відносимо І. Драча і Б. Олійника, - деталізація світу й себе в ньому, що виявляється і в семантизації займенника Я, який служить передусім для вияву свого зовнішнього світу, осягнення себе на тлі реального життя - реальних подій і реальних осіб. У поетичній мові цих авторів „особистісне Я” (сам мовець) досить поширений тип. Причому часто безіменність дешифрується певними хронотопними характеристиками, що відтворюють автобіографічні моменти життя письменників, тобто контекст ідентифікує „,авторське Я”, напр.: Поверніть мене до класу срібним покликом дзвінка. Зажурилась моя парта, третя парта од вікна (Б. Олійник, Прощальний вальс), Я, хлопчик-семиліток, вийшов з хати. Двигтіла ніч, і страхом волохатим Кректала, рвалась, репала земля (І. Драч, Київьке небо).

Поети-інтроверти на передній план висувають потребу осмислення свого внутрішнього світу, тому частотність вживання прономінатива Я в аналізованих збірках Л. Костенко та М. Вінграновського настільки висока (із 154 віршів М. Вінграновського він помічений у 147, а в Л. Костенко — iз 231 поезії в 204), що вже само по собі є підтвердженням особливої його ролі як засобу

\footnotetext{
${ }^{11}$ Ю. Н. Тынянов, Проблемы стихотворного анализа, Москва 1965, с. 83.

${ }^{12}$ О. Н. Селив ерстова, Местоимения в языке и речи, Москва 1988, с. 156.
} 
презентації ліричного героя, ідентичного з авторським Я. Отже, займенник Я у цих поетів функціонує переважно як „особистісне Я”, причому, на відміну від екстравертів, таке Я автор тільки зрідка конкретизує хронотопною атрибутикою, що є узагальненим тлом для вияву „особистісного Я” (інтроверти сприймають довкілля блоками, не деталізуючи його): Труїти душу кожен раз $\boldsymbol{Я}$ вже не можу - будь я проклят! Пищать дощчі, і води топлять I душу, і терпіння, й час (М. Вінграновський, Не починайся. Ні з очей...), Внизу далеко смужечка дороги. Сніги і я. Над присмерком смерек - усіх печалей білі епілоги (Л. Костенко, Шпиль Туги), Я забуваю сумніви і сум. Я воду п'ю у Сувиді з криниці (Л. Костенко, Сувид).

Причому в Ліни Костенко „Я особистісне” має ту визначальну рису, що за його референт править особа (автор), яка уособлює себе із природою, частиною всесвіту, вона існує в нерозривному зв'язку із цілим, живиться від нього й пізнає себе в ньому. Таке філософське осмислення „Я особистісного” виявляється в злитті Я + природа, що переростає в МИ й репрезентується соціативною конструкцією: Убоге поле, ми з тобою Крези, десь наше зерно - гори золоті (Л. Костенко, Стриптизи осені). Персонажами в таких поезіях є ліричне Я і персоніфіковані елементи природи, до яких часто звертається ліричний герой: Пробачте, осінь, я вас не впущу. У вас мороз на скронях (Л. Костенко, Пробачте, осінь...). У поета-інтроверта Л. Костенко „психологічний, інтимний, почуттєвий вимір космічного Часу”'13 спричинює злиття „особистісного Я” („Я власне”) i „Я уособленого” (,Я чуже”) — „Я’” вже не особа, а певний предмет довкілля, риси якого перейняв ліричний герой, виражаючи свою філософію буття: $\boldsymbol{Я ~ н а ~ п л а н е т і ~ д е р е в о ~ л ю д с ь к е . ~ М е н е ~ в е с ь ~ ч а с ~ п і д р у б у ю т ь ~ п і д ~ к о р і н ь ~}$ (Л. Костенко, Я на планеті...), Я дерево, я сніг, я все, щзо я люблю. I, може, це і є моя найвища сутність (Л. Костенко, Послухаю цуей дощ).

Аналогічне явище, хоча й не таке частотне, як у Л. Костенко, спостерігається і в поетичній мові М. Вінграновського. Занурений у „власне Я”, ліричний герой, співвідносний із автором, уособлює себе з природою, відображаючи в такому уособленні гармонію буття, вічність і безмежність всесвіту: Іду у безсмертному морі, i море іде у мені!.. I я відчуваю, щзо жив я, щзо житиму ще і живу, Бо морю й землі не чужий я, Бо їх я собою зову (М. Вінграновський, Морської осені).

Сутність „функціонального Я” полягає в осмисленні свого призначення, ролі в різних сферах життя, історії народу, світі та ін. У цьому разі контекст виконує функцію тла, на якому актуалізуються шукання ліричного Я, окреслюється його місце в житті. „Функціональне Я” практично не трапляється в поезії М. Вінграновського, можливо, через вузькість тематики аналізованої збірки, де репрезентована інтимна лірика поета. Однак і в Л. Костенко „функціональне Я” розмите, нечітко виражене, часом переплітається 3 „Я особистісним”: Час поле тихою сапою. На світі бойня і гризня. А я іду до водопою, веду крилатого коня (Л. Костенко, Час поле тихою сапою). У поетів-екстравертів „Я функціональне" більше конкретизоване, роль у житті референта такого Я чіткіше окреслена: Нi, я не обраний на ролю месіанську. Усе, щуо мав, і все, щуо на віку Дісталося мені від долі-посіванки (Б. Олійник, Мій борг), По тому поети налягають на вірші ( $і$ я серед них, грішний) (Б. Олійник, А все було...ніколи).

Семантика „зіставного я” розвивається завжди на тлі ослаблення семантики „Я особистісного”, коли на передній план висувається інформація, пов’ язана

\footnotetext{
${ }^{13}$ О. Пах льов ська, Невидимі причали, [в:] Ліна Костенко, Річка Геракліта, Київ 2011, с. 13.
} 
3 певними етнокультурними чинниками й історичним екскурсом: Може, це вже через тисячу літ - $і$ і не я вже, розбуджена в генах... (Л. Костенко, Затінок, сутінок, день золотий), Це було зо дві тисячі з гаком літ, Коли стрів мене вражий спис (Б. Олійник, Я б спокійно лежав під вагою століть). За допомогою зіставного ряду Я - ВИ - ВСІ І. Драч репрезентує філософію минущості життя: $\boldsymbol{Я}$ помру (вітер суглоби доріг хусткою витер, Ви помрете (вітер перекотиполе з корінням видер), Всі помруть, перекотиполем зійдуть (І. Драч, Балада про жайворонків). Однак випадків уживання займенника Я як виразника референта „Я зіставне” в поезії аналізованих ліриків не так багато.

Скупо репрезентована й семантика „Я ліричного персонажа”, оскільки вона не виражає авторського Я, а притаманна персонажам, які висловлюють своє ставлення до дій чи слів інших персонажів. Семантика такого Я поширена в епічних творах, а не в ліриці, тому, природно, в мові аналізованих збірок вона трапляється рідко. Однак зазначимо, що найбільш поширене „Я ліричного персонажа" в поезії екстравертів. Особливий інтерес становлять у цьому сенсі поезії, написані чоловіками, де ліричним героєм є жінка. Контекстуальний вияв семантики Я показовий з гендерного погляду, бо дозволяє зрозуміти, як уявляє поет-чоловік мовний образ жінки: займенник Я оточений лексемами зі зменшено-пестливим значенням, фразеологічними зворотами, текст насичений метафорами й епітетами, тобто мова референта „Я ліричного персонажа” максимально експресизована: Не злякалася я дощу, Підіткнула синеньке платтячко I чекала тебе за березами, Хочеш вір, а хочеш не вір (I. Драч, Етюд - копія записки), $\boldsymbol{Я}$ - дівчина, $\boldsymbol{\boldsymbol { A }}$ - скрипка тонкостанна. $\boldsymbol{Я}$ - ніжна ніч у зорянім вінку (I. Драч, Ніж у Сониі), $\boldsymbol{Я}$ до тебе хоч... мертвою, Мій єдиний, прийила (Б. Олійник, Балада вірності).

Семантика „Я опредметненого” розкривається за допомогою стилістичного процесу персоніфікації предметів, явищ чи абстрактних понять. I якщо для інтровертивного типу мислення більше притаманна персоніфікація натурфактів, що відображає прагнення особи злитися з природою, осягнути філософію всього сущого на землі (порівн. у Л. Костенко: Я річку побачила раптом. Питаю: - А хто ж ти така? - Я Альта, я Альта, я Альта! - тонесенько плаче ріка (Л. Костенко, Я хочу на озеро Світязь), то екстраверти персоніфікують і натурфакти, й артефакти, таким чином виявляється їхнє прагнення навіть в образному сприйнятті довкілля деталізувати його, напр., в I. Драча поезія Балада про відро вся побудована на персоніфікації відра, що виявляється за допомогою прийому анафори - кожна строфа починається з фрази $Я$ - цинкова форма (три строфи) і $Я$ - зрізаний конус (одна строфа). У цього поета ліричним персонажем, який говорить, стає й вухо, й сірник тощо.

Референт „Я особистісне” в інтимній ліриці вербалізується як нерозривна єдність з референтом ,любовне ТИ (твій)”, породжуючи таким чином семантику „любовне МИ (наш)”. Як відомо, ТИ - другий після ліричного Я семантичний центр вірша, одна зі складових його „сюжетної схеми”. Ліричне Я майже завжди передує в діалозі з ,Я -іншим” або з ТИ. Навіть якщо в ліричному тексті з'являється МИ, то воно зазвичай складається з „Я + ТИ’, де ТИ - найчастіше ліричний герой чи героїня. Такий характер висловлювання С. Бройтман називає ,інтерсуб’єктним”: не аналітичне розрізнення „Я” та „інший”, а їхня задана нерозривна інтерсуб'єктна цілісність ${ }^{14}$.

\footnotetext{
${ }^{14}$ С. Н. Бройтман, Историческая поэтика: хрестоматия-практикум, Москва 2004.
} 
Інтерсуб'єктність інтимної лірики притаманна мові всіх аналізованих письменників, оскільки це узагальнювальна риса поетики такого різновиду ліричного жанру. Однак у кожного з них рівень інтерсуб'єктної цілісності різний, що залежить, очевидно, від різних ознак натури автора - від психічного устрою, темпераменту, набутих рис характеру та інших внутрішніх властивостей людини, напр., у М. Вінграновського „любовне ТИ” переважно залишається безіменним, а тому читач сприймає його як узагальнений образ коханої жінки: Tu mym! ти тут! Кохана, ти - як світ, Початок і кінець твій загубився (М. Вінграновський, Ти тут! Ти тут!), Лиш ти одна, мені одна лиш ти Мій палиш сон і душу мою палиш (М. Вінграновський, Моя осінь). У поезії цього автора послідовно простежуємо гармонію злиття „особистісного Я” 3 ,любовним ТИ” як вияв глибини кохання: Щасливий я - В мене ім'я твоє, І я люблю, Яка мені ти $\epsilon .$. Твоя дорога - Мої там кроки (М. Вінграновський, Щаслива пісня). Для ліричного героя поета-інтроверта, замкненого в собі, важливо зробити світ „своїм”, привласнити його. Така ,інтимізація” допомагає вибудувати цілісний світ: Щока, та тінь, та тінні очі, і ми самі на самоті... (М. Вінграновський, Щока та тінь...).

Інтерсуб'єктність у мові поезій Л. Костенко виявляється значно стриманіше. Займенник ТИ, що має референт коханий, трапляється десь у 15\% аналізованих поезій. Л. Костенко, як і М. Вінграновський, не схильна до опису портрета коханого, вербалізуються переважно відчуття, породжувані спілкуванням із ним: Я чую слова, де ні слова нема. Я теж, як і ти, від любові німа (Л. Костенко, Отримала я ненаписаний лист), а також зрідка глибоке почуття від утрати коханого: Як рідко ти приходиш в мої сни! Великим смутком спогади омиті (Л. Костенко, Весна).

У творах поетів-екстравертів семантика займенника ТИ значно ширша. Дейктичність, притаманна ТИ в комунікативних ситуаціях реального життя, у поезії, напр., І. Драча визначає необмеженість вибору адресата висловлювання. Це й узагальнений співрозмовник, і конкретна особа, зокрема кохана, й неістота, й абстрактне явище: $\boldsymbol{T u} л і г$ туди, у землю, до джерел, Голубити їх голубе коріння (I. Драч, Над могилою батька), О мужносте! Як твос ім'я, - Хіба ти не принишкла тут?! (I. Драч, Мати троянд), 3 тобою бути, і рости, і ряст топтати (І. Драч, Величальна Грузіі). Інтерсуб'єктність, таким чином, в I. Драча виявляється меншою мірою, але так само яскраво, як і в попередніх поетів:

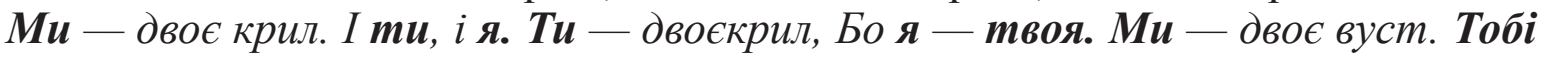
й мені В губах ичих глузд На самім дні (І. Драч, Поема для жіночого голосу).

Визначальною рисою вживання займенника ТИ в мові поезій Б. Олійника $є$ висока частотність його референтної співвіднесеності з конкретною особою, відомою з контексту, безіменність, таким чином, нівелюється: Та, батьку... Та де ж ти? Ми ж тридиять віків тебе ждали! (Б. Олійник, На березі вічносmi), Де стрічаєш ти, мамо, поштаря із райцентру (Б. Олійник, Та від білої хати...). Часом автор звертається до узагальненого читача 3 метою надати пораду чи висловити передбачення, що свідчить про високий рівень контактної спроможності поета та його відкритість усьому світу: Tu їх ще побачиш, зів 'ялих, непевних, як дим, В уламках надій, щз розбились о кремінь на друзки (Б. Олійник, Марафон), Тобі ж природа усього вділила! То хазяйнуй у суверенній вміло, А не ходи ногами догори! (Б. Олійник, Інвектива - 1). Однак „любовне ТИ” в Б. Олійника таке ж безіменне, а отже, дуже інтимізоване, сокровенне, як і в інших поетів, напр.: Летів до тебе турманом через моря i дні, Спадав із неба тугою, а ти сміялась: „Ні” (Б. Олійник, Летів до тебе турманом) та ін. 
Аналіз смислових домінант, репрезентованих займенниками 1-ї та 2-ї особи в мові лірики І. Драча, Б. Олійника, М. Вінграновського, Л. Костенко, які належать до різних психотипів, виявив такі закономірності.

Ліричне Я всіх поетів семантизується переважно за допомогою референта „Я особистісне”, що значеннєво співвідносне з особою автора, „авторським Я”, „первинним автором”, тобто це сам поет, який сприймає життя у всіх його проявах і відображає складність, багатогранність людської натури.

У суб'єктивно ліричних творах ніколи не звучить ім'я автора, тобто його суб'єкт безіменний, але ідентичність авторського й ліричного Я виражається саме займенниками 1-ї особи однини. Показово, що поети-екстраверти певною мірою ідентифікують своє Я автобіографічною атрибутикою, тоді як інтроверти осмислюють своє Я, абстрагуючись від реальних життєвих подій, зазвичай як частину природи, часточку всесвіту, тобто відтворюють світ у собі, а не себе в світі. Через це в поетів-інтровертів виявляється тенденція до семантичного зближення „Я особистісного” 3 „Я уособленим”: ліричний герой органічно входить у природу, розчиняється в ній, стає ï частиною. Зрідка таке зближення спостерігаємо 3 ,Я зіставним” і „Я функціональним”. У поетів-екстравертів I. Драча та Б. Олійника змістове наповнення займенника Я значно ширше, воно звернене назовні: крім „Я особистісного”, це і „Я функціональне”, і „Я зіставне”, i ,Я опредметнене”, i „Я ліричного персонажа”.

По-різному в аналізованих поетів уживається інтерсуб'єктність (єдність „Я особистісного” з „ТИ”, „ВИ”, зокрема 3 „ТИ, ВИ любовним”), хоча загалом це специфічна риса інтимної лірики, репрезентована займенниками, що створюють узагальнений „суб’єкт переживань”. Найбільш послідовно й виразно інтерсуб'єктність виявляється в ліриці інтроверта М. Вінграновського, при цьому він уникає конкретизації, деталізації референтів. Ліричне Я і ТИ в поета стає акумулятором усього комплексу душевних переживань героя.

Характерною рисою творчої манери Л. Костенко $є$ помірний вияв інтерсуб'єктності, а це свідчить про те, що „суб'єкт переживань” у ії поезії значною мірою індивідуалізований, за ним убачаємо передусім внутрішній світ самої авторки, а референт займенника ТИ залишається дещо відстороненим.

Інтерсуб' єктність у поетів-екстравертів теж має свою специфіку: вона поширена не тільки в інтимній ліриці, а й у громадянській, у них часто „Я особистісне” і „Я функціональне” поєднується 3 „ТИ конкретного співрозмовника" й „ТИ узагальненим”, породжуючи „МИ, об’єднане спільними цінностями, спільною долею”. 